\title{
Attitude of Students towards Lecture Teaching Methods in Agriculture in Secondary Schools in Mukaa Sub-County of Makueni County, Kenya
}

\author{
Esther Mumbi Nzomo, James Obara, Agnes Nkurumwa Oywaya
}

\begin{abstract}
Successful teaching and learning of agriculture in secondary schools in Kenya depends mostly on correct use of teaching methods whose activities target learning senses. Attitude of agriculture students are quite often acquired through teaching and learning process. Agriculture students' attitude can be changed by using a variety of teaching and learning methods. The purpose of this study was to determine students' attitude towards lecture teaching method in agriculture in secondary schools in Mukaa Sub County of Makueni County. The study was conducted to ascertain the Learners' Preference, willingness and eagerness to participate in agricultural activities in secondary schools in Mukaa Sub-county of Makueni County.This study employed a descriptive research design. The target population of the study consisted of 1773 Form three agriculture students in secondary schools in Mukaa Sub County. A sample size of 120 respondents was randomly selected from a sampling frame of 1773 Form three students in the four wards in Mukaa Sub-county. A semi-structured questionnaire was used to gather data from the respondents. To establish reliability of the research instruments a pilot study was carried out using 30 randomly selected secondary school Form three agriculture students in Nzaui Sub County. Face and internal validity of the instrument was established by the supervisors from the department of Agricultural Education and Extension. Quantitative data were coded and analyzed using the Statistical Package for Social Sciences. Qualitative data was analyzed using document report analysis. The results were presented in frequencies, means and percentages. The study established that the attitude of students towards the lecture method was positive. The study recommends that teachers of agriculture should be given in-service training on how to improve the lecture method of teaching agriculture to enhance the teaching and learning process and also combine various teaching methods of agriculture as the situation demands to make teaching and learning effective.
\end{abstract}

Index Terms - Student Attitude, Lecture Teaching Methods, Agriculture Subject.

\section{INTRODUCTION}

Agriculture has an immense impact to humanity in terms of global food supplies, hunger alleviation, economic development and provision of employment ${ }^{1}$. In Sub-Saharan Africa, the agricultural sector has become a dominant provider of employment, and it remains crucial for economic

Esther Mumbi Nzomo, Department of Agricultural Education and Extension, Egerton University, P.O.Box 546 - 20115 Egerton

James Obara, Department of Agricultural Education and Extension, Egerton University, P.O.Box 546 - 20115 Egerton

Agnes Nkurumwa Oywaya, Department of Agricultural Education and Extension, Egerton University, P.O.Box 546 - 20115 Egerton growth ${ }^{2}$. Moreover in most parts of Africa food security is still a critical issue and therefore food production will continue to be a major focus of agricultural education and training institutions ${ }^{3}$.

Agriculture is a vocational subject which is a vital tool in preparing people for a new phase of rural development ${ }^{4}$. According to ${ }^{1}$ agriculture in other parts of the world for example United States of America (USA), is a subject that is designed to help students develop agricultural appreciation encompassing knowledge and information needed by any workers to enter and make progress in employment on a useful and productive basis. In Malaysia vocational education is meant to produce a workforce which is educated, skilled and having positive attitude ${ }^{3}$. In Bangladesh, technical subjects are highly recognized due to their contribution to national development in areas of manpower creation and running of industries ${ }^{5}$.

Agriculture became officially established in Kenyan school's curriculum in several phases in the slow development of colonial education ${ }^{6}$. With the introduction of the 8-4-4 system of education in Kenya in 1985, all the schools started offering agriculture (Republic of Kenya, $1984 ;{ }^{7}$. The subject is taught so that the youth can appreciate the role agriculture plays in the economy of the country ${ }^{8}$. Additionally school agriculture is an attempt to inculcate attitudes, knowledge and practical skills in students needed to improve agricultural production ${ }^{1}$. Effective teaching and learning of agriculture subject is done through use of different methods of teaching 9. Effectiveness of these methods depends, to a great extent, on the attitude bear towards them.

A study done by ${ }^{10}$ found out that the attitude of students plays a significant part in any satisfactory explanation of learning methods used in agriculture subject. As reported by ${ }^{3}$, many students develop negative attitude towards teaching methods of agriculture subject, probably due to the fact that teachers are unable to satisfy their aspiration or goals.

Effective teaching and learning takes place when the teacher knows which method to use in a particular situation to meet specific goals ${ }^{5}$. In using teaching methods, teachers are faced with the task of placing the students in an educational setting tailored to the students learning. The setting in which services are rendered has a strong influence on the students' attitude ${ }^{3}$. Different teaching methods are available for the teacher to use in communicating attitudes, ideas, knowledge, and skills to the students in order to achieve the desired objectives of a given lesson. This study was limited to investigating students' attitude towards lecture method of 
teaching agriculture.

\section{(A) Statement of the Problem}

Debate over the most effective teaching method to be used in teaching agriculture subject is a strong challenge now facing agriculture teachers in secondary schools. Some agriculture teachers believe in imposing knowledge on students, others suggest that students be guided and allowed to discover knowledge on their own. The pedagogical value of the lecture teaching method used to teach agriculture subject continues to be questioned, specifically whether agriculture students gain knowledge, or learn sufficiently from it. To what extent the lecture teaching method contribute to the learning process of agriculture students and under what circumstances the teaching methods may prove a viable component of the teaching process remain unresolved. Attitude of agriculture students are quite often acquired through the teaching and learning process. Attitude can be changed through teaching, using a variety of teaching and learning methods. Attitude once established helps to shape the experiences the student has with the teaching methods in agriculture subject. Although attitude changes gradually, agriculture students constantly form new attitude and modify old one when they are exposed to new information and new experiences. Teachers should generate the greatest opportunity for students to learn and technically manage instruction by using teaching methods that allow students to explore the world, discover knowledge, reflect and think critically with careful monitoring and guidance from the teacher.

Teaching method affects the responses of students and determines whether they are interested, motivated and involved in a lesson in such way as to engage in a good learning. Since teaching among other factors plays a significant role in developing attitude of agriculture students towards a teaching method, this study therefore seeks to determine students' attitude towards lecture teaching method in agriculture subject in secondary schools in Mukaa sub county of Makueni County, Kenya.

\section{(B) Objectives of the Study}

The purpose of the study was to determine students' attitude towards lecture teaching method attitude towards lecture teaching methods in secondary schools in Mukaa Sub-county of Makueni County. By determining their attitude towards lecture teaching method, the study may be beneficial in building a knowledge base to understand the student learning experiences at secondary schools from a different angle and to help teachers to reflect on effective teaching in terms of using various teaching methods.

\section{(C) Conceptual Framework}

The conceptual framework was developed from the reviewed related literature. Under this frame work, selected methods of teaching agriculture namely; cooperative, demonstration, field trips and lecture methods are the independent variables of the study. This variable was measured by determining how agriculture students feel and respond to cooperative, demonstration, field trips and lecture methods. The dependent variable is the students' attitude towards the teaching methods. The variable was measured by determining the preference, willingness and eagerness of learners to participate in agricultural activities when a selected method was used in teaching through a Likert scale questions. The interaction between independent and dependent variables is further influenced by intervening variables. The intervening variables influence the effects of the independent variable on the dependent variables ${ }^{11}$. In this study intervening variables are gender, and school category which were controlled through random selection of the participants.

\section{(D) Theoretical Frame Work}

This study was guided by the Theory of Reasoned Action (TRA). This model developed by ${ }^{12}$ defines the links between beliefs, attitudes, norms, intentions, and behaviors of individuals ${ }^{13}$. TRA is relevant in that when students' believe that a certain teaching method will have a significant effect on their learning of agriculture subject, then this method will be to their benefit and the students will take a favorable attitude towards it. If the teaching method has no significance effect on the students learning of agriculture subject, the student will take unfavorable attitude towards the method.

\section{RESEARCH METHODOLOGY}

\section{(A) Location of the Study}

The study was conducted in Mukaa Sub-county of Makueni County, Kenya, which covered an area of 629.9 square kilometers. The Sub-county borders Kajiado County to the West, Makindu Sub-county to the South, Nzaui Sub-county to the East and Machakos County to the North. The Sub-county lies in the Arid and Semi-arid zones of the Northern region of the County.

\section{(B) Research Design}

In this study, a descriptive survey research design was used. This design provided self-reported facts about the participants' attitudes. The target population of the study consisted 1773 Form Three students' taking agriculture in all the secondary schools in Mukaa Sub-County. Random sampling was used to select 120 respondents for the study.

\section{(C) Target Population}

The target population of the study consisted 1773 Form Three students' taking agriculture in all the secondary schools in Mukaa Sub-County.

\section{(D) Sampling Procedure and Sample Size}

The sampling units for the study consisted of all Form three agriculture students in Kasikeu, Kilome, Kiongwani, and Maiani wards of Mukaa Sub-county. Mukaa Sub- county was purposively selected for the study due familiarity of the researcher to the area and its accessibility. The four wards in Mukaa sub-county were purposively included in the study since they are easily accessible. Mukaa Sub-county has 40 secondary schools distributed in four wards. The 40 secondary schools were also purposively selected because they have offered agriculture for at least five years. ${ }^{14}$ recommend that for a descriptive study of this nature, it requires a minimum sample of 100 subjects. This sample was increased by $20 \%$ to 120 to compensate for sample mortality and respondents' inability to participate as recommended by 15 and to ensure a high level of statistical significance. Students in each secondary school were proportionately selected because the number of students in each school 
varied. A total sample size of 120 Form Three agriculture students was randomly selected from Extra-County, County and Sub-County schools to participate in the study. Form three agriculture students were preferred because they had already selected the subject unlike the students in Form One and Two.

\section{(E) Instrumentation}

A questionnaire which consisted of a number of both open-ended and closed-ended questions were used to enable the researcher to gather data within a shorter time and allowed standardization, ease of use, and anonymity. The questionnaire was pretested using 30 secondary school agriculture students in Nzaui Sub County, which did not form part of the main study. Validity of the instruments was ensured by input from the supervisors from the department of Agricultural Education and Extension. Data was collected and then analyzed using the Statistical Package for the Social Sciences (SPSS) Version 20. Qualitative data was analyzed along set themes in the use of lecture method of teaching of agriculture subject. The results were presented in frequencies, means and percentages.

\section{RESULTS AND DISCUSSIONS}

This section presents data on students' attitude towards lecture teaching methods in agriculture in secondary schools in Mukaa Sub County. To ascertain students' attitude towards lecture teaching methods in agriculture in secondary schools, a five point scale was used. Agriculture students were provided with statements and asked to choose the level of agreement by indicating that they: Where $1=$ Strongly Disagree (SD), 2=Disagree (D), 3=Uncertain (U), 4=Agree (A) $5=$ Strongly Agree (SA). The findings are summarized in Table 1, 2 and 3.

Table 1 Overall Descriptive Statistics on Attitude of Students towards Lecture Method of Teaching Agriculture

\begin{tabular}{llllll}
\hline & $\mathrm{N}$ & Minimum & Maximum & Mean & Std. Deviation \\
\hline AT LECTURE & 112 & 2.75 & 4.83 & 3.6510 & 0.3910 \\
\hline
\end{tabular}

$\mathrm{N}=112$
The overall attitude of students towards lecture method of teaching agriculture was highly positive as displayed in table 1. Students portrayed a positive attitude towards conversational interactions with their agriculture teachers.
The overall mean of the statements used to examine attitude towards lecture method was established to be 3.65. This mean depicts that, generally, students liked the lecture method of teaching agriculture.

Table 2Positively Stated Items used to Test Students' Attitude towards' Lecture Method of Teaching Agriculture

\begin{tabular}{|c|c|c|c|c|}
\hline Statement & Min & $\operatorname{Max}$ & Mean & Std. Dev. \\
\hline $\begin{array}{l}\text { I enjoy when my teacher tells me about agricultural activities during } \\
\text { agriculture lesson }\end{array}$ & 2.00 & 5.00 & 4.29 & 0.76 \\
\hline $\begin{array}{l}\text { Good learning atmosphere is created when my teacher inform me } \\
\text { about agricultural activities during agriculture lesson }\end{array}$ & 1.00 & 5.00 & 4.08 & 0.87 \\
\hline $\begin{array}{l}\text { I rely on what my teacher notify me to learn what I need to know } \\
\text { during agriculture lesson }\end{array}$ & 1.00 & 5.00 & 3.51 & 1.31 \\
\hline $\begin{array}{l}\text { Teacher teaching through talking makes me gain confidence in } \\
\text { agriculture }\end{array}$ & 1.00 & 5.00 & 3.66 & 1.30 \\
\hline $\begin{array}{l}\text { I understand agriculture better when agriculture teacher discuss } \\
\text { agricultural ideas with me }\end{array}$ & 1.00 & 5.00 & 4.25 & 1.00 \\
\hline $\begin{array}{l}\text { Listening while my agriculture teacher carries out discussion increases } \\
\text { my participation in agriculture lesson }\end{array}$ & 1.00 & 5.00 & 4.19 & 0.99 \\
\hline $\begin{array}{l}\text { Teacher - student discussion makes agriculture lessons more } \\
\text { enjoyable }\end{array}$ & 2.00 & 5.00 & 4.59 & 0.72 \\
\hline $\begin{array}{l}\text { Teacher conversing agricultural ideas during agriculture } \\
\text { lesson prepares me very well for tests }\end{array}$ & 2.00 & 5.00 & 4.25 & 0.80 \\
\hline
\end{tabular}

Of the twelve statements testing students' attitude towards lecture method of teaching, four statements generated means that exposed students uncertain attitudes towards some aspects of the lecture method of teaching. The statements are presented in table 3 along with their means and standard deviations.

\section{Table 3 Descriptive Statistics of Negatively Stated Statements for Lecture Method of Teaching}

\begin{tabular}{llccc}
\hline Statement & Min & Max & Mean & Std. Dev. \\
\hline $\begin{array}{l}\text { Topics taught by my teacher through talking in agriculture class always } \\
\text { go out of my memory }\end{array}$ & 1.00 & 5.00 & 2.99 & 1.39 \\
$\begin{array}{l}\text { I perform poorer in agriculture tests and examinations in topics taught } \\
\text { through practical. }\end{array}$ & & & \\
I like agriculture lessons that make participate in activities more than & & 5.00 & 2.24 & 1.21 \\
$\begin{array}{l}\text { when the teacher just talks } \\
\begin{array}{l}\text { I master less agriculture content when a teacher teaches through } \\
\text { dialogue }\end{array}\end{array}$ & 5.00 & 2.98 & 1.36 \\
\end{tabular}


Three of the negatively stated statements in favor of the lecture method of teaching attained responses whose attitudes rated average. This indicates that the respondents were uncertain whether they disagree with the negativity of the method. This means that their attitude towards lecture method was uncertain. One statement 'I perform poorer in agriculture tests and examinations in topics taught through practical' $(\mu=2.24)$ rated very low showing that the respondents actually disagreed that lecture method was considered better than learning through activity-centered methods. The analysis of the positive and negative statements used to examine the respondents' attitude towards lecture method of teaching agriculture reveals that, whereas the attitude rated above average, the results also exposed that their attitude towards the negatively aspects of the lecture method was also uncertain. This provides evidence of negativity towards the method. The probable reason for this mixed attitude could be that they are used to the method of teaching until they have the belief that it is a good method.

\section{CONCLUSION AND RECOMMENDATIONS}

The purpose of this study was to investigate students' attitude towards the use of lecture method of teaching agriculture in secondary schools in Mukaa Sub-county of Makueni County, Kenya. Lecture method was the independent variable, the dependent variable was the students' attitude towards the lecture teaching methods and the intervening variables were gender and school category. The researcher settled on this study due to the prevailing perplexity in choice of the most appropriate method to apply when teaching agriculture. The researcher opted to obtain and measure responses from students that reveal their attitude and preference towards the lecture method. The study found out that the attitude of students towards lecture teaching method in agriculture is positive in the sampled secondary schools in Mukaa sub County of Makueni County. This means that the students accept that lecture method worthwhile. However a scrutiny of the statements used to examine the attitude uncovered that students like participative aspects of the method, implying that they like the method.

The following are the recommendations for further study emanating from the study findings:

Efforts should be made by the Teachers' Service Commission in organizing for relevant in-service programmes for teachers of agriculture in secondary schools where they would update teaching methods and enhance the teaching and learning process.

\section{REFERENCES}

[1] 1. Wong, L.; Fong, M., Student attitudes to traditional and online methods of delivery. Journal of Information Technology Education: Research 2014, 13 (1), 1-3.

[2] 2. Darko, R. O.; Offei-Ansah, C.; Shouqi, Y.; Jun-Ping, L., Challenges in the teaching and learning of agricultural science in selected public senior high schools in the Cape Coast Metropolis. Agricultural Science 2015, 3 (1), 13-20.

[3] 3. Lamidi, W. A., Assessment methods as effective tools for learning outcomes of students in senior secondary schools in Ila-Orangun, south western Nigeria. International Journal of Development and Sustainability 2013, 2 (2), 485-492.
[4] 4. Amukowa, W., A call to reform secondary schools in Kenya. American International Journal of Contemporary Research 2013, 3 (1), 92-102.

[5] 5. Auwal, A., Effects of teaching method on retention of Agricultural Science knowledge in senior secondary schools of Bauchi Local Government Area, Nigeria. International Journal of Science and Technology Education Research 2013, 4 (4), 63-69.

[6] 6. Glennerster, R.; Kremer, M.; Mbiti, I.; Takavarasha, K., Access and quality in the Kenyan education system: A review of the progress, challenges and potential. Office of the prime minister of Kenya 2011.

[7] 7. Ngugi, D.; Isinika, A.; Temu, A.; Kitalyi, A., Agricultural education in Kenya and Tanzania (1968-1998). Nairobi: RELMA (Sida) 2002.

[8] 8. Muchiri, J. M.; Odilla, G. A.; Kathuri, N., Students 'perception Of Secondary School Agriculture: A Case of Meru Central District, Kenya. Asian Journal of Social Sciences and Humanities 2013, 2 (4), 129-135.

[9] 9. Thoron, A. C.; Burleson, S. E., Students' Perceptions of Agriscience When Taught through Inquiry-Based Instruction. Journal of A gricultural Education 2014, 55 (1), 66-75.

[10] 10. Jebson, S. R.; Hena, A. Z., StudentsAttitude Towards Science Subjects In Senior Secondary. IMPACT: International Journal of Research in Applied, Natural and Social Sciences (IMPACT: IJRANSS) 2016, 117-124.

[11] 11. Kothari, C. R., Research methodology: Methods and techniques. New Age International: 2004.

[12] 12. Fishbein, M., leek Ajzen (1975), Belief, Attitude, Intention, and Behavior: An Introduction to Theory and Research. Read-ing, MA Addison-Wesley 1981

[13] 13. Farzaneh, N.; Nejadansari, D., Students' attitude towards using cooperative learning for teaching reading comprehension. Theory and Practice in Language Studies 2014, 4 (2), 287.

[14] 14. Fraenkel, J. R.; Wallen, N. E.; Hyun, H. H., How to design and evaluate research in education. McGraw-Hill New York: 1993; Vol. 7.

[15] 15. Balian, E. S., How to design, analyze, and write doctoral or masters research. ERIC: 1988. 